\title{
Red Snapper Fish Resources (Etelinae Subfamily) in Pasi of Lease Islands Maluku Province
}

\author{
Delly D. P. Matrutty \\ Doctoral Degree, Department of Fisheries Resource Utilization, IPB, Bogor, Indonesia \\ E-mail: dellypaulin@yahoo.com
}

S. Martasuganda

Department of Fisheries Resource Utilization, IPB, Bogor, Indonesia

D. Simbolon

Department of Fisheries Resource Utilization, IPB, Bogor, Indonesia

A. Purbayanto

Department of Fisheries Resource Utilization, IPB, Bogor, Indonesia

Received: September 6, 2013 Accepted: October 2, 2013 Published: December 25, 2013

doi:10.5296/jee.v4i2.4962ＵRL: http://dx.doi.org/10.5296/jee.v4i2.4962

\begin{abstract}
Red snapper (Etelinae subfamily) is demersal fishery resources. It becomes export commodity because of having economic value, fish food quality and delicious taste. Besides, red snapper becomes recreational fishing object in various tropic and subtropical countries. For years, people on Lease Islands, Central Maluku have been hereditary catching red snapper in specific sites called "pasi". Caught red snapper types in pasi by Lease's people are called as "bae" fish. This study aims to: 1) identify caught red snapper types in pasi of Lease Islands. 2) determine the distribution, density and red snapper potential in pasi. Data sampling is conducted through acoustic survey, interview and observation. Density of fish is gained by BioSonics, 2004; 2010. Identification result shows that deep sea red snapper (Etelinae subfamily) called as "bae fish" on Lease Islands consists of 4 types, they are: Etelis
\end{abstract}




\section{Macrothink}

radiosus, E. coruscans, E carbunculus and Aphareus rutilans. These fish types inhabit waters at about 90-140 m deep, while its total length (TL) are ranging from 30-85 cm. Total density of fish school is 0.0477 individual $/ \mathrm{m}^{2}$, the maximum sustainable yield (MSY) is 400.33 individual/year and total allowable catch (TAC) is 320,267 individual/year.

Keywords: Bae fish, Pasi, Potential and distribution 


\section{Introduction}

Red snapper (Etelinae subfamily) is an important demersal fishery resources because it becomes a high valuable export commodity as found in Hawaiian Islands and exploited for more than 100 years (Moffit, 2003). This fish is also utilized for fishing recreational sites (Haight et al 1993a). Commercial use of these snapper types in Hawaii is dominated by four Etelinae species, they are: Etelis carbunculus, E coruscans, pristipomoides filamentosus and Aprion virescens. Andrade (2003) declares that this fish is the most important component of deep sea demersal fishery in Hawaii and other areas in Pacific, Atlantic and Hindian. Demersal fishing activities in Arafura and Timor sea by Taiwan and Thailand vessels under license of Darwin have been going on since 1970s. Up to 1990, demersal fishing in Australian shelf waters have exploited intensively by fishing vessel from Japan, Taiwan and Thailand. Examples of targeted types include Red Snapper (Snapper, Lutjanidae), Lencam (Emperors, Lethrinidae), Kuwe (Travellies, Carangidae) and Kurisi (threadfin beam, Nemipteridae) (Prisantoso and Badrudin 2010).

Acquired information from historical records of Taiwan's haul in Australian waters shows that red snapper production in 1988 is 1.019 ton, and in the following years, this production falls into 39 ton (Prisanoso and Badrudin, 2010). Due to a drastic haul reduction, from 1990, this demersal fishery is claimed as fully exploited and since that year, red snapper haul license is discontinued for all fishing vessels. Similar condition is reported by Fry et al (2006). His research around Lihir Island, Papua New Guinea states that deep sea demersal fishery stock is highly vulnerable although used technology is still standard. Hence, it is recommended that preventive action should be realized including accurate haul long-term monitoring if red snapper stock is exploited commercially.

Red snapper catching have been hereditary caught for years by the local fisherman. These fish types are called as "bae" fish, while the fishing zones located at specific site are called as "pasi" (Matrutty 2011). Fishing is carried on to fulfill daily needs of the society. However, these fish types did not recorded specifically by statistic numbers in Maluku.

Current issue is that the exploitation of red snapper tends to increase on Ambon Island, Seram Island and Lease Islands waters during the period of last \pm 5 years.

To meet this challenge, it needs to do a study or research on what level of the available red snapper potential. Thus, this study is more focused on specific sites called pasi on Lease Islands. These sites are considered as potential fishing zone for bae fishing. This study aims to (1) identify caught red snapper varieties in pasi and (2) determine the distribution, density and red snapper potential in pasi of Lease Islands.

\section{Research Methodology}

This study is conducted on Lease Islands (including Haruku, Saparua and Nusalaut Island), Central Maluku Regency, Maluku Province. Data sampling is conducted for 12 months (July, 2011-June, 2012). Required data in this study is primary data obtained through survey, interview and observation. The survey is acoustic survey to gain fish school density distribution in pasi by using Bioconic. For the survey fluency, site of each pasi is determined 
using GPS (Global Positioning System). Furthermore, GPS recordings are mapped using Argis 10 program in order to gain distribution map of pasi, then it is set as research station in this site (Figure 1).

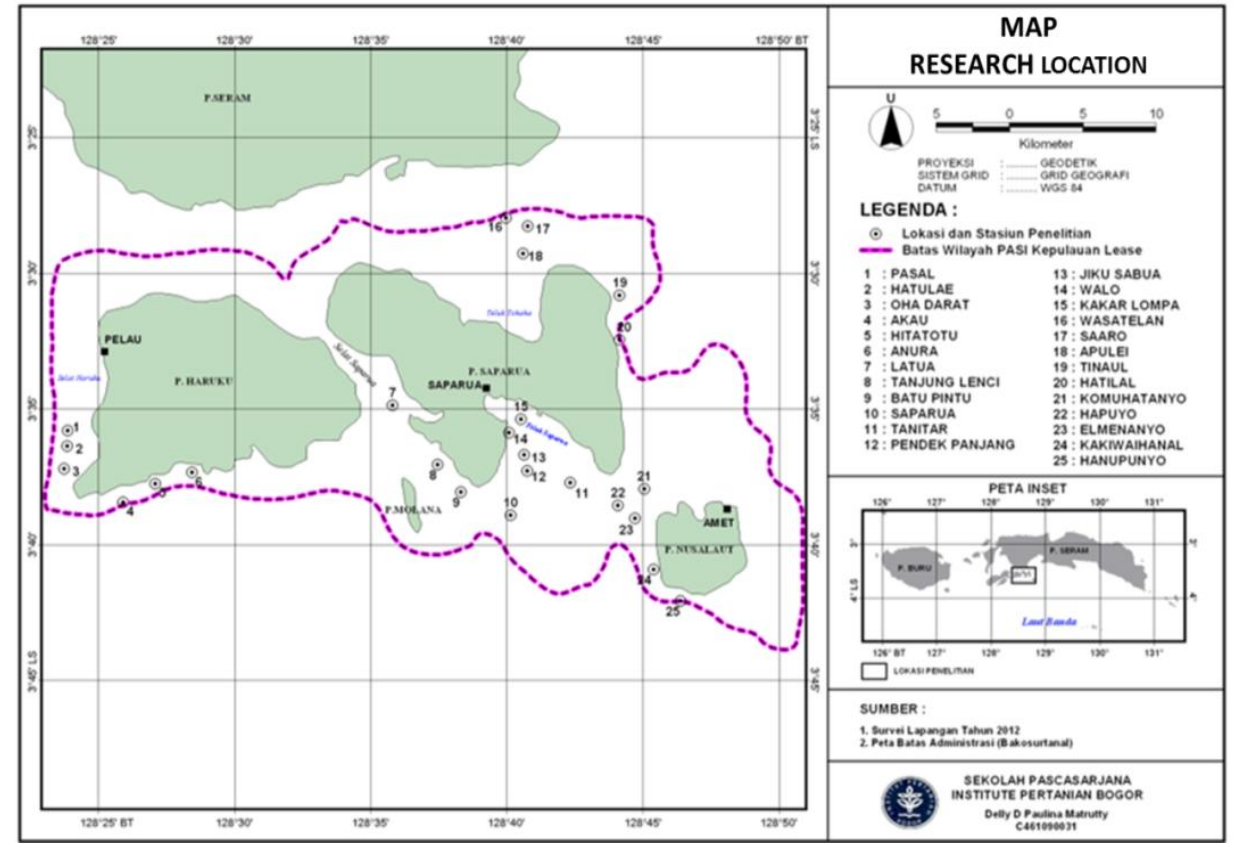

Figure 1. Location map and distribution map of pasi as research station

Data recording is gained through echo-integration technique and measurement of fish section acoustically by the data sampling speed of 3 times per second in every pasi location during the voyage. The other ways of interviewing and observation are conducted by living with every fisherman during their activities of haul in pasi everyday. Recorded data includes position, varieties, quantity and deep of water when the fishes caught. The next fish identification process is conducted by following identification manual book written by Allen (1985); Anderson and Allen (2001); and Allen, et al, (2003).

Fish school density analysis is gained through formula (BioSonics, 2004; 2010) as follows:

$$
\mathbf{F P C M}=\mathrm{Sv} / \overline{\sigma_{\mathrm{bs}}}
$$

In this case, FPCM is fish per cubic meter, $\mathrm{Sv}$ is volume backscattering strength and $\sigma_{\mathrm{bs}}$ is backscattering cross-section or acoustically calculated fish section. Volume backscattering strength (Sv) acquired by:

$$
\mathrm{Sv}=10 * \log \left[\rho_{\mathrm{c}} *\left(\sum \mathrm{P} / \sum \text { Samples }\right)\right]
$$

In this case, $\rho_{c}$ is system scale constant and $\Sigma \mathrm{P}$ is sound intensity samples which is reflected from detected target. System scale constant is acquired from:

1

$$
\rho_{\mathrm{c}}=\pi^{*} \mathrm{pw} * \mathrm{c} *\left(10^{(\mathrm{SI} / 10)}\right)^{2} *\left(10^{(\mathrm{RS} / 10)}\right)^{2} * \mathrm{E}\left\lceil\mathrm{b}^{2}\right\rceil
$$


Here, $\pi=3,14159 \ldots$, pw is sound pulse width (second), $\mathrm{c}$ is speed of sound underwater $(\mathrm{m} / \mathrm{sec}$.$) , SL is source level (\mathrm{dB} \mu \mathrm{Pa}), \mathrm{RS}$ is sensitivity of receiver $(\mathrm{dB})$ and $\mathrm{E}\left(\mathrm{b}^{2}\right)$ is radiation pattern of transducer factor.

Calculation of standing stock (SS) and maximum sustainable yield (Py/MSY) are calculated by formula approach according to Gulland and Schaffer, (1968) it is:

\section{Standing Stock $(S S)=$ Density $(D) \times$ Total Area Width}

information:

$$
P y / M S Y=C x M x S S
$$

$\mathrm{C}=$ Empiric constant $(U, \mathrm{~J})$

$\mathrm{M}=$ Natural Mortality (1)

$\mathrm{SS}=$ Standing stock

\section{Results and Discussion}

Pasi is specific fishing zone for red snapper Etelinae subfamily (bae fish) on Lease Islands. Fishing activity by local community is conducted by using simple hand line by hook number of 9, 8, 7 and 6 . This traditional activity is moved by a 5-7 $\mathrm{m}$ width of paddled boat.

Red snapper fishing activity have been going on every day of the year on Haruku, Saparua and Nusalaut Island. This activity is mostly done by fisherman community on Saparua Island. There are several causes on this matter, for example; (1) amount of red snapper fis herman on Haruku and Nusalaut Island is limited; (2) orientation of fisherman on both islands are more focused on pelagis fishing activity in comparison with demersal fish; (3) fisherman's knowledge and mastery of pasi sites on Saparua Island is better than the others two islands because of different fishing orientation; (4) habits of people on Saparua Island which consider bae fish as a symbol to build fraternity relationship among people. Differences of utilization level in every region give a strong implication against the amount and size of red snapper in every pasi.

\subsection{Potential and Width of Fishing Ground (Pasi)}

Based on interview with the community, it is found that 25 pasi are used for red snapper (Etelinae subfamily) fishing zone by traditional fisherman on Lease Islands (Figure 1). Output of participative mapping is followed by mapping process (digitazion) using Archview 10 program to obtain the area measurement of every pasi. This process is used in the calculation of potential red snapper source. Name, location and area of each pasi are presented in Table 1. 
Table 1. Name, Location and Area of each pasi.

\begin{tabular}{|c|c|c|c|c|}
\hline No. & Name of Pasi & Latitude & Longitude & Area (ha) \\
\hline 1 & Pasal & $03^{\circ} 35.792^{\prime} \mathrm{S}$ & $128^{\circ} 23.877^{\prime} \mathrm{E}$ & 499.04 \\
\hline 2 & Hatu lae & $03^{\circ} 36.361^{\prime} \mathrm{S}$ & $128^{\circ} 23.859^{\prime} \mathrm{E}$ & 435.80 \\
\hline 3 & Oha darat & $03^{\circ} 37.205^{\prime} \mathrm{S}$ & $128^{\circ} 23,744^{\prime} \mathrm{E}$ & 438.18 \\
\hline 4 & Akau & $03^{\circ} 38.431^{\prime} \mathrm{S}$ & $128^{\circ} 25.912^{\prime} \mathrm{E}$ & 339.35 \\
\hline 5 & Hitatotu & $03^{\circ} 37.779^{\prime} \mathrm{S}$ & $128^{\circ} 27.096^{\prime} \mathrm{E}$ & 299.05 \\
\hline 6 & Anura & $03^{\circ} 37.345^{\prime} \mathrm{S}$ & $128^{\circ} 28.432^{\prime} \mathrm{E}$ & 438.33 \\
\hline 7 & Latua & $03^{\circ} 34858^{\prime} \mathrm{S}$ & $128^{\circ} 35.804^{\prime} \mathrm{E}$ & 958.01 \\
\hline 8 & Tanjung lenci & $03^{\circ} 37.045^{\prime} \mathrm{S}$ & $182^{\circ} 37.463^{\prime} \mathrm{E}$ & 698.25 \\
\hline 9 & Batu pintu & $03^{\circ} 38.056^{\prime} \mathrm{S}$ & $128^{\circ} 38.323^{\prime} \mathrm{E}$ & 399.78 \\
\hline 10 & Saparua & $03^{\circ} 38.911^{\prime} \mathrm{S}$ & $128^{\circ} 40.145^{\prime} \mathrm{E}$ & 674.41 \\
\hline 11 & Tanitar & $03^{\circ} 37.765^{\prime} \mathrm{S}$ & $128^{\circ} 43.572^{\prime} \mathrm{E}$ & 1380.00 \\
\hline 12 & Pendek panjang & $03^{\circ} 35.710^{\prime} \mathrm{S}$ & $128^{\circ} 40.644^{\prime} \mathrm{E}$ & 587.48 \\
\hline 13 & Jiku sabua & $03^{\circ} 37.298^{\prime} \mathrm{S}$ & $128^{\circ} 40.774^{\prime} \mathrm{E}$ & 628.05 \\
\hline 14 & Walo & $03^{\circ} 36.440^{\prime} \mathrm{S}$ & $128^{\circ} 40.330^{\prime} \mathrm{E}$ & 242.18 \\
\hline 15 & Kakar lompa & $03^{\circ} 36.890^{\prime} \mathrm{S}$ & $128^{\circ} 40.109^{\prime} \mathrm{E}$ & 744.00 \\
\hline 16 & Wasatelan & $03^{\circ} 27.965^{\prime} \mathrm{S}$ & $128^{\circ} 39.981^{\prime} \mathrm{E}$ & 320.24 \\
\hline 17 & Saaro & $03^{\circ} 29.597^{\prime} \mathrm{S}$ & $128^{\circ} 43.229^{\prime} \mathrm{E}$ & 854.89 \\
\hline 18 & Apulei & $03^{\circ} 31.214^{\prime} \mathrm{S}$ & $128^{\circ} 44.023^{\prime} \mathrm{E}$ & 2931.66 \\
\hline 19 & Tinaul & $03^{\circ} 32.315^{\prime} \mathrm{S}$ & $128^{\circ} 44.084^{\prime} \mathrm{E}$ & 850.98 \\
\hline 20 & Hatilal & $03^{\circ} 37.840^{\prime} \mathrm{S}$ & $128^{\circ} 43.670^{\prime} \mathrm{E}$ & 184.88 \\
\hline 21 & Komuhatanyo & $03^{\circ} 39.390^{\prime} \mathrm{S}$ & $128^{\circ} 44.620^{\prime} \mathrm{E}$ & 849.44 \\
\hline 22 & Hapuyo & $03^{\circ} 40.710^{\prime} \mathrm{S}$ & $128^{\circ} 45.310^{\prime} \mathrm{E}$ & 613.52 \\
\hline 23 & Elmenanyo & $03^{\circ} 41.720^{\prime} \mathrm{S}$ & $128^{\circ} 45.770^{\prime} \mathrm{E}$ & 557.70 \\
\hline 24 & Kakiwaihanal & $03^{\circ} 42.050^{\prime} \mathrm{S}$ & $128^{\circ} 46.190^{\prime} \mathrm{E}$ & 534.88 \\
\hline \multirow[t]{2}{*}{25} & Hanupunyo & $03^{\circ} 42.040^{\prime} \mathrm{S}$ & $128^{\circ} 46.210^{\prime} \mathrm{E}$ & 318.94 \\
\hline & Total & & & 16,779.01 \\
\hline
\end{tabular}

\subsection{Types and Distribution}

There are 12 (twelve) kinds of caught fish during the study by 3 families, they are Lutjanidae, Serranidae and Priacanthidae. Identification result shows that known red snapper types by Lease's community called as "bae" consist of 4 (four) species, they are: Etelis radiosus, E.coruscans, E. carbunculus and Aphareus rutilans spesies (Table 2, Figure 2).

Table 2. Local name, family, species, and fishing depth

\begin{tabular}{llllr}
\hline No & Local Name & Family & Species & $\begin{array}{c}\text { Fishing } \\
\text { depth } \\
(\mathrm{m})\end{array}$ \\
\hline 1 & Bae laki-laki & Lutjanidae & Etelis radiosus & $100-110$ \\
2 & Bae ekor bandera & Lutjanidae & Etelis coruscans & $110-130$ \\
3 & Baeparampuang & Lutjanidae & Etelis carbunculus & $120-140$ \\
4 & Baegamuru & Lutjanidae & Aphareus rutilans & $90-100$
\end{tabular}




\section{Macrothink}

\begin{tabular}{lllll}
5 & Silapa & Lutjanidae & Pristopomoides sp. & $60-70$ \\
6 & Kakap_1 & Lutjanidae & Lutjanus sp. & $50-60$ \\
7 & Kakap_2 & Lutjanidae & Lutjanus spp. & $50-60$ \\
8 & Kakap_3 & Lutjanidae & Paracaesio kusakarii & $50-60$ \\
9 & Garopah_1 & Serranidae & Epinephelus morrhua & $50-60$ \\
10 & Garopah_2 & Serranidae & Cephalopholis spiloparaea & $40-50$ \\
11 & Garopah_3 & Serranidae & Saloptia powelli & $40-50$ \\
12 & Mata Bulan & Priacanthidae & Heteropriacanthus cruentatus & $40-50$ \\
\hline
\end{tabular}

Taxonomically, red snapper types (Etelinae subfamili) consist of 5 genera, they are: Aphareus, Aprion, Etelis, Pristipomoides and Rhandallichtys (Allen 1985). Research of Hukom et al (2007) found 4 of 5 genera at Makassar Strait and Celebes Sea, they are: Aphareus, Aprion, Etelis, and Pristopomoides. It is found 3 of 5 genera on Lease Islands, they are Aphareus, Etelis and Pristopomoides. Bae fish is considered under two genera i.e. Aphareus and Etelis. Hence, it can be concluded that pasi on Lease Islands region is characterized by 2 (two) genera i.e. Aphareus and Etelis.

Distribution of fish based on biosonic shows that demersal species in pasi is distributed at the depth of 40-250 m. While the distribution of bae species based on tabulation result of fishing depth from bae fisherman shows that bae parampuang (Etelis carbunculus) is a species inhabiting the depth ranging from 120-140 m, followed by bae ekor bandera (E coruscans) at about $110-130 \mathrm{~m}$ depth, bae laki-laki (E. radiosus) ranging at $100-110 \mathrm{~m}$, and A. rutilans ranging at 90-100 $\mathrm{m}$ depth.
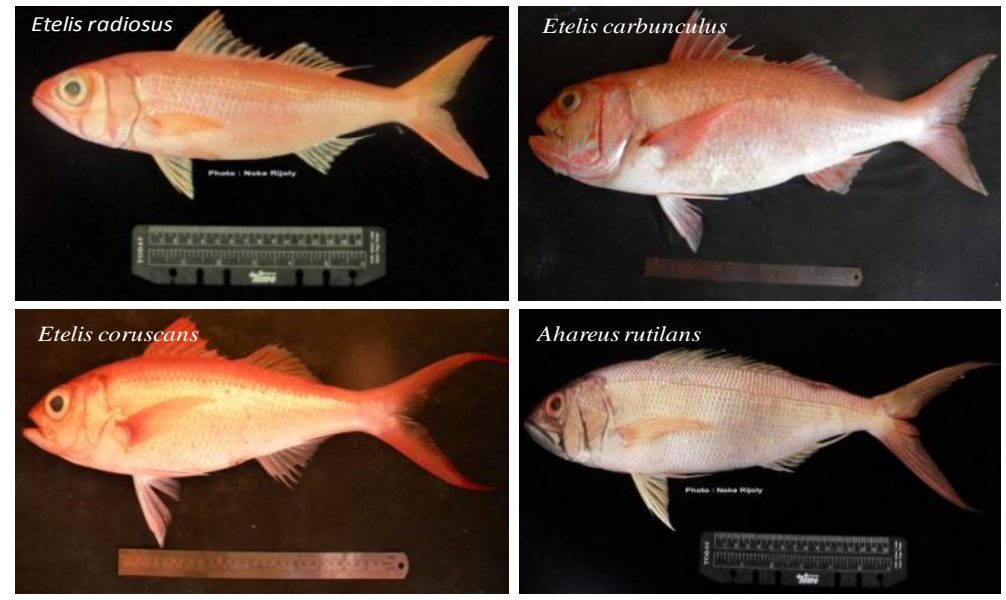

Figure 2. Caught red snapper (bae fish) types on Lease Islands according to

Anderson dan Allen (2001) is that the distribution of red snapper types is found in varied depth of sea. Species of fish in sea under Etelinae subfamily is found at minimum depth of $85.3 \mathrm{~m}$ and maximum depth of $284 \mathrm{~m}$ in continental slope. In continental slope of Hawaiian Islands, exactly at the northwest area, this fish is found at the depth of 60-300 m (Mitsuyasu 2003). In the main island of Hawaiian Islands, demersal fish including Etelinae species is caught at the depth of 100-400 m (Moffitt 2003). Aphareus rutilans species inhabits at the depth of 20-240 m (Anderson and Allen 2001), E. Carbunculus spesies inhabits at depth of 90-400 $\mathrm{m}$ in an extreme shelf break and upper slope boundary (Hunter 2001; Andrade 2003). 


\section{Macrothink}

While Moffit and Parrish (1989) state that the biggest concentration of teen red snapper in Kaneohe Strain, Hawaii is found at the depth ranging from 60-100 m.

This depth range, comparing with depth calculation result during the study, can be concluded that caught red snapper types on Lease Islands inhabit the similar depth as the other waters locations.

Caught deep sea red snapper on Lease Islands is found at the edge of slope with relative steep as well as in the peak of underwater hill. The example of underwater profile gained from echosounder recordings is presented at Figure 3.

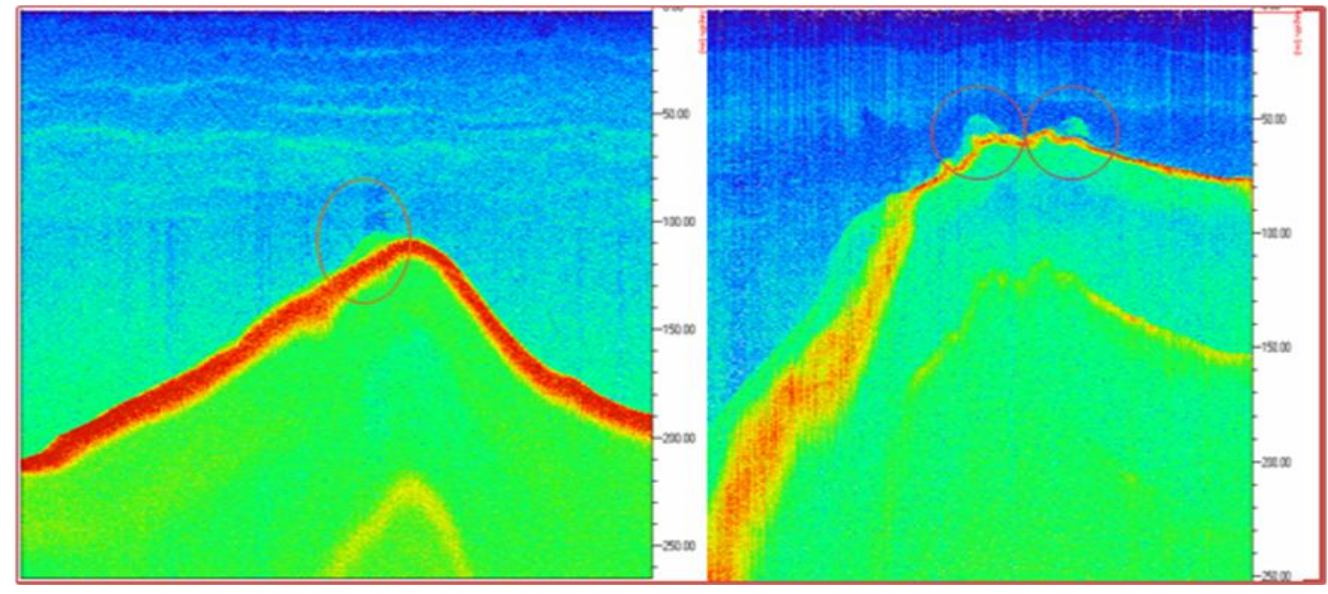

Figure 3. Example of biosonic recordings for Red Snapper on Lease Islands

\subsection{Amount and Size of Fish}

Calculated haul of the fisherman for 12 months (June, 2011-June, 2012) is 445 individual. Ikan bae laki-laki (Etelis radiosus) is 171 individual (38.430 \%), followed by bae gamuru (Aphareus rutilans) is 126 individual (28,315\%), bae ekor bandera (E. coruscans) 99 individual (22.23\%) and bae parampuang (E. Carbunculus) is 49 individual (11.011\%). This condition represents that the amount of haul definitely depends on the distribution depth of every species. Distributed species E.carbunculus inhabiting the lower depth than the other species has the smallest amount. Perhaps, it is occurred because fisherman has an obstacle related to hand line tools which are still traditional. Those fishermen said that the deeper sea is, the bigger fish can be caught. On the contrary, cut off or lost of fishhook turns to bigger because waters' currents and topography are steep and deep.

Size of caught fish during the study varies for every species. Etelis radiosus species has about $30-91 \mathrm{~cm}$ in Total Lenght, E coruscans has about $31-72 \mathrm{~cm}$, E carbunculus has about 36-85 $\mathrm{cm}$ and Aphareus rutilans has about $32-71 \mathrm{~cm}$. Interval analysis result at size level shows that those four species are mostly caught at size range of $38-45 \mathrm{~cm}$ followed by fish size length of 46-53 cm (Figure 4). 


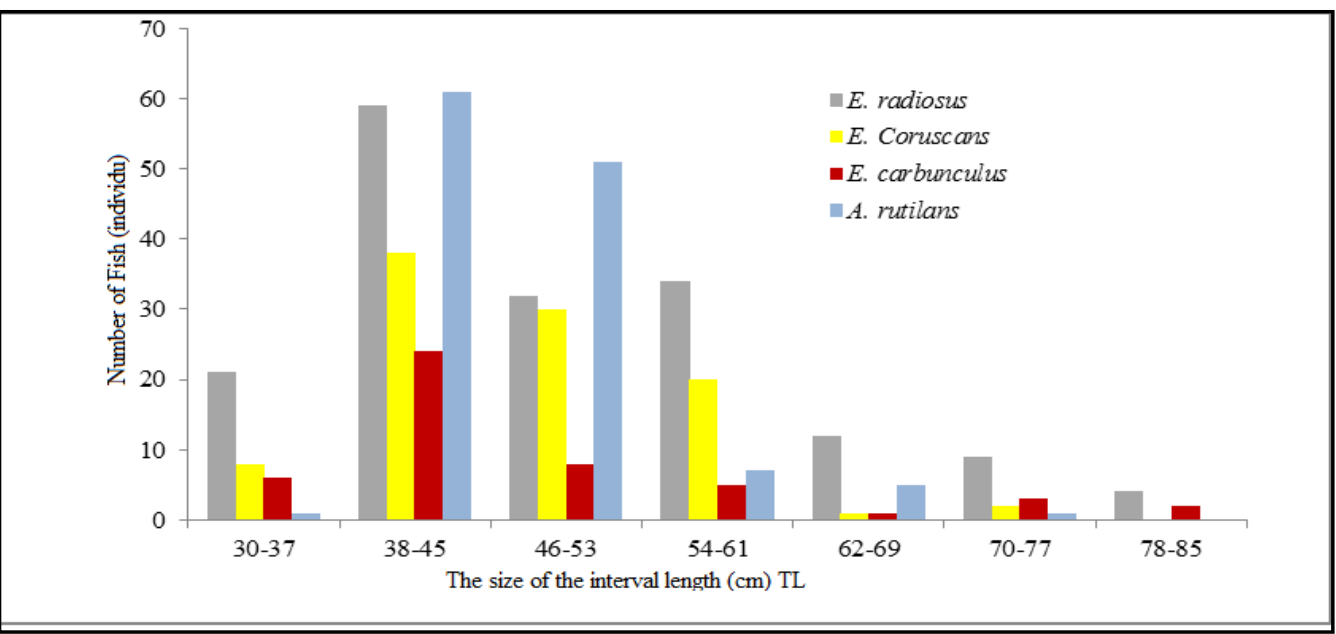

Compared with the other researches on the size range of mature fish types, caught fish on Lease Islands is classified as young fishes which are improper to be caught.

Wide variety of maximum size and length for mature red snapper species (Etelinae subfamily) based on this study is presented in Table 3.

Tabel 3. Size variety of red snapper (Etelinae subfamily)

\begin{tabular}{|c|c|c|c|c|c|}
\hline No & Species & Location & Source & $\begin{array}{l}\text { Lmax } \\
(\mathrm{cm})\end{array}$ & $\begin{array}{l}\mathrm{Lm} \\
(\mathrm{cm})\end{array}$ \\
\hline \multirow[t]{2}{*}{1} & Etelis coruscans & Hawaii & Wiliams and Lowe 1997 & 104 & 55.5 \\
\hline & & Vanuatu & Bouard and Grandperiin 1984 & 70 & 56.5 \\
\hline \multirow[t]{4}{*}{2} & Etelis carbunculus & Hawaii & Everson 1984 & 104 & $55, .5$ \\
\hline & & Hawaii & Smiith and Kostlan 1991 & 76.2 & 41.9 \\
\hline & & NW Hawaii & Grigg and Tonoue 1984 & 76.2 & 41.9 \\
\hline & & Tonga & Langi and Langi 1987 & 114 & 57 \\
\hline 3 & E. radiosus & - & - & - & - \\
\hline \multirow[t]{2}{*}{4} & A. rutilans & North Marianas & Ralston and Wiliams 1988b & 141.4 & 72.2 \\
\hline & & - & Froese and Pauly 2000 & 110 & 58.3 \\
\hline
\end{tabular}

Source: Andrade (2003)

Lmax = Maximum length

$\mathrm{Lm}=$ Length at maturity

Ralston and Kawamoto (1988) states that mostly red snapper stock falls on growth overfishing because the caught fishes are mostly at its young age. This fish type matures late, has long age range and slow-moving growth which gives a sensitive effect of overfishing (Ralston and Miyamoto 1983;Manooch,1987; Ralstondan and Williams,1989; Sudekum et al, 1991; Haight et al 1993a,. Mees, 1993;Pilling et al 2000). If size range oriented fishing is still continued before its optimum size or maturity, it is worried because of its population reduction . 


\subsection{Red Snapper Potential on Lease Islands Region}

Based on calculation of biosonic records in all pasi, it is found that value of red snapper density is 0.0477 individual $/ \mathrm{m} 2$ and biomass is $0.00005 \mathrm{ton} / \mathrm{m} 2$. Analysis result reveals that standing stock of red snapper in this region is 800.67 individual with biomass of 0.91 ton, and maximum sustainable yield (MSY) based on individual amount as a whole in Lease waters region is 400.33 individual/year with potential biomass of 0.455 ton/year, while the total allowable catch based on individual amount is 320.267 individual/year and based on biomass of 0.364 ton/year. Value of density (D), standing stock (SS), maximum sustainable yield (MSY) and TAC are presented in Table 4 and 5.

Table 4. Name of Pasi, area (ha), density (m2), standing stock (SS)

\begin{tabular}{|c|c|c|c|c|c|c|}
\hline \multirow[b]{2}{*}{ No. } & \multirow[b]{2}{*}{ Name of Pasi } & \multirow[b]{2}{*}{ Area (ha) } & \multicolumn{2}{|c|}{ Density (m2) } & \multicolumn{2}{|c|}{ Standing Stock (SS) } \\
\hline & & & Individual & $\begin{array}{c}\text { Biomass } \\
\text { (Ton) }\end{array}$ & Individual & $\begin{array}{c}\text { Biomass } \\
\text { (Ton) }\end{array}$ \\
\hline 1 & Pasal & 499.035 & 0.054 & 0.00003 & 26.948 & 0.015 \\
\hline 2 & Hatu lae & 435.795 & 0.069 & 0.00004 & 29.913 & 0.017 \\
\hline 3 & Oha Darat & 438.180 & 0.016 & 0.00009 & 6.827 & 0.039 \\
\hline 4 & Akau & 339.352 & 0.079 & 0.00008 & 26.707 & 0.027 \\
\hline 5 & Hitatotu & 299.051 & 0.094 & 0.00008 & 28.111 & 0.024 \\
\hline 6 & Anura & 438.327 & 0.066 & 0.00006 & 29.017 & 0.028 \\
\hline 7 & Latua & 958.012 & 0.010 & 0.00006 & 9.503 & 0.058 \\
\hline 8 & Tanjung Lenci & 698.250 & 0.038 & 0.00006 & 26.324 & 0.042 \\
\hline 9 & Batu Pintu & 399.776 & 0.100 & 0.00003 & 39.977 & 0.013 \\
\hline 10 & Saparua & 674.411 & 0.021 & 0.00009 & 14.028 & 0.061 \\
\hline 11 & Tanitar & 1379.995 & 0.016 & 0.00004 & 22.591 & 0.058 \\
\hline 12 & Pendek Pjng & 587.476 & 0.030 & 0.00008 & 17.389 & 0.049 \\
\hline 13 & Jiku Sabua & 628.047 & 0.013 & 0.00004 & 8.416 & 0.025 \\
\hline 14 & Walo & 242.182 & 0.048 & 0.00006 & 11.627 & 0.015 \\
\hline 15 & Kakar Lompa & 744.003 & 0.013 & 0.00003 & 9.538 & 0.022 \\
\hline 16 & Wasatelan & 320.235 & 0.029 & 0.00002 & 9.396 & 0.006 \\
\hline 17 & Saaro & 854.885 & 0.007 & 0.00005 & 6.070 & 0.044 \\
\hline 18 & Apulei & 2931.661 & 0.017 & 0.00005 & 51.040 & 0.147 \\
\hline 19 & Tinaul & 850.984 & 0.033 & 0.00004 & 28.338 & 0.034 \\
\hline 20 & Hatilal & 184.878 & 0.113 & 0.00007 & 20.960 & 0.013 \\
\hline 21 & Komuhatanyo & 849.439 & 0.018 & 0.00003 & 15.290 & 0.025 \\
\hline 22 & Hapuyo & 613.521 & 0.090 & 0.00003 & 55.217 & 0.018 \\
\hline 23 & Elmenanyo & 557.700 & 0.049 & 0.00008 & 27.216 & 0.045 \\
\hline 24 & Kakiwaihanal & 534.883 & 0.044 & 0.00006 & 23.535 & 0.032 \\
\hline \multirow[t]{2}{*}{25} & Hanupunyo & 318.935 & 0.126 & 0.00004 & 40.154 & 0.013 \\
\hline & Total & 16779.013 & 0.048 & 0.00005 & 800.668 & 0.909 \\
\hline
\end{tabular}


Potential at MSY level (Table 5) shows the difference between one pasi and the others. The highest potential is found in Pasi Hapuyo with MSY of 27.808 individual/year. This Pasi is located at southwest side of Nusalaut island at position of $03^{\circ} 40,710^{\prime} \mathrm{S}$ and $128^{\circ} 45,310 \mathrm{E}$ and the lowest potential is at Pasi Saaro with MSY value of 3.00 individual/year. This Pasi is located at north side of Saparua Island at $03^{\circ} 29,597^{\prime} \mathrm{S}$ and $128^{\circ} 43,229^{\prime} \mathrm{E}$. Perhaps, the difference of fish potential occurred because of uneven fishing in waters. Other cause is pasi locations mastery is only owned by certain and experienced fisherman. Especially for those fishermen on Saparua Island who exploit more on demersal fishes, including red snapper or bae fish, compared with fisherman of Haruku and Nusalaut Island who are tend to catch pelagis fish types. Identification of pasi in every region shows that the number of pasi on Saparua Island region is more than the number of pasi on Haruku and Nusalaut Island by 14, 6 and 5 pasi respectively.

Table 5. Name of pasi, area (ha), MSY and TAC (Total Allowable Catch)

\begin{tabular}{rlrrrrr}
\hline \multirow{2}{*}{ No. } & Name of Pasi & Area (ha) & \multicolumn{2}{c}{ MSY } & \multicolumn{3}{c}{ TAC } \\
\cline { 3 - 7 } 1 & Pasal & 499.035 & 13.47 & 0.007 & 10.779 & 0.006 \\
2 & Hatulae & 435.795 & 14.96 & 0.009 & 11.965 & 0.007 \\
3 & Oha Darat & 438.180 & 3.41 & 0.020 & 2.731 & 0.016 \\
4 & Akau & 339.352 & 13.35 & 0.014 & 10.683 & 0.011 \\
5 & Hitatotu & 299.051 & 14.06 & 0.012 & 11.244 & 0.010 \\
6 & Anura & 438.327 & 14.51 & 0.014 & 11.607 & 0.011 \\
7 & Latua & 958.012 & 4.75 & 0.029 & 3.801 & 0.023 \\
8 & Tanjung Lenci & 698.250 & 13.16 & 0.021 & 10.530 & 0.017 \\
9 & Batu Pintu & 399.776 & 19.99 & 0.006 & 15.991 & 0.005 \\
10 & Saparua & 674.411 & 7.01 & 0.030 & 5.611 & 0.024 \\
11 & Tanitar & 1379.995 & 11.30 & 0.029 & 9.036 & 0.023 \\
12 & Pendek Pjng & 587.476 & 8.69 & 0.024 & 6.956 & 0.020 \\
13 & Jiku Sabua & 628.047 & 4.21 & 0.013 & 3.366 & 0.010 \\
14 & Walo & 242.182 & 5.81 & 0.008 & 4.651 & 0.006 \\
15 & Kakar Lompa & 744.003 & 4.77 & 0.011 & 3.815 & 0.009 \\
16 & Wasatelan & 320.235 & 4.70 & 0.003 & 3.758 & 0.003 \\
17 & Saaro & 854.885 & 3.03 & 0.022 & 2.428 & 0.017 \\
18 & Apulei & 2931.661 & 25.52 & 0.073 & 20.416 & 0.059 \\
19 & Tinaul & 850.984 & 14.17 & 0.017 & 11.335 & 0.014 \\
20 & Hatilal & 184.878 & 10.48 & 0.006 & 8.384 & 0.005 \\
21 & Komuhatanyo & 849.439 & 7.64 & 0.013 & 6.116 & 0.010 \\
22 & Hapuyo & 613.521 & 27.61 & 0.009 & 22.087 & 0.007 \\
23 & Elmenanyo & 557.700 & 13.61 & 0.022 & 10.886 & 0.018 \\
24 & Kakiwaihanal & 534.883 & 11.77 & 0.016 & 9.414 & 0.013 \\
25 & Hanupunyo & 318.935 & 20.08 & 0.006 & 16.062 & 0.005 \\
\hline & Total & 16779.01 & 400.33 & 0.455 & 320.267 & 0.364 \\
\hline & & & & & Individual & Weight (Ton) \\
\hline
\end{tabular}


Based on area calculation of 14 pasi on Saparua Island, it is acquired that total area of 11.454 ha becomes the main fishing location around this island region. By the total of areal width, if it is multiplied with fish school density based on biosonic recordings, it is found that red snapper potential source on Saparua Islands's waters is 400 individual/ha. Then, maximum sustainable yield (MSY) is 200 individual/year with total allowable catch (TAC) is 160,086 individual/year (Table 6).

Table 6. Name, area, density, standing stock, MSY and TAC of red Snapper on Saparua Island.

\begin{tabular}{rlrrrrr}
\hline No & Name of Pasi & \multicolumn{1}{c}{ Area } & Density & \multicolumn{1}{c}{ SS } & \multicolumn{1}{c}{ MSY } & \multicolumn{1}{c}{ TAC } \\
\hline 1 & Latua & 958.012 & 0.0099 & 9.5035 & 4.7517 & 3.801 \\
2 & Tanjung Lenci & 698.250 & 0.0377 & 26.3240 & 13.1620 & 10.529 \\
3 & Batu Pintu & 399.776 & 0.1000 & 39.9774 & 19.9887 & 15.991 \\
4 & Saparua & 674.411 & 0.0208 & 14.0277 & 7.0139 & 5.611 \\
5 & Tanitar & 1379.995 & 0.0164 & 22.5905 & 11.2953 & 9.036 \\
6 & Pendek Panjang & 587.476 & 0.0296 & 17.3893 & 8.6946 & 6.955 \\
7 & Jiku Sabua & 628.047 & 0.0134 & 8.4158 & 4.2079 & 3.366 \\
8 & Walo & 242.182 & 0.0480 & 11.6272 & 5.8136 & 4.650 \\
9 & Kakar Lompa & 744.003 & 0.0128 & 9.5383 & 4.7692 & 3.815 \\
10 & Wasatelan & 320.235 & 0.0293 & 9.3957 & 4.6978 & 3.758 \\
11 & Saaro & 854.885 & 0.0071 & 6.0697 & 3.0348 & 2.428 \\
12 & Apulei & 2931.661 & 0.0174 & 51.0402 & 25.5201 & 20.416 \\
13 & Tinaul & 850.984 & 0.0333 & 28.3378 & 14.1689 & 11.335 \\
14 & Hatilal & 184.878 & 0.1134 & 20.9596 & 10.4798 & 8.384 \\
\hline & Total & $11,454.7950$ & 0.0349 & 400 & 200.110 & 160.086 \\
\hline
\end{tabular}

There are 6 (six) pasi on Haruku Island region with total pasi area is 2.449,74 ha. This location have been being fishing zones for fisherman living around this island region. By the total of areal width, if it is multiplied with density of fish based on biosonic recordings, it is found that red snapper potential source on Haruku Island is 154 individual/ha with maximum sustainable yield (MSY) is 76.990 individual/year and TAC is 61,6 individual/year (Table 7).

Tabel 7. Name, area, density, standing stock, MSY and TAC of red snapper on Haruku Island

\begin{tabular}{cllcccc}
\hline No & Name of Pasi & Area & Density & \multicolumn{1}{c}{ SS } & \multicolumn{1}{c}{ MSY } & \multicolumn{1}{c}{ TAC } \\
\hline 1 & Pasal & 499.035 & 0.0540 & 26.9479 & 13.4739 & 10.7792 \\
2 & Hatu Lae & 435.795 & 0.0686 & 29.9130 & 14.9565 & 11.9652 \\
3 & Oha Darat & 438.180 & 0.0156 & 6.8268 & 3.4134 & 2.7307 \\
4 & Akau & 339.352 & 0.0787 & 26.7070 & 13.3535 & 10.6828 \\
5 & Hitatotu & 299.051 & 0.0940 & 28.1108 & 14.0554 & 11.2443 \\
6 & Anura & 438.327 & 0.0662 & 29.0172 & 14.5086 & 11.6069 \\
\hline
\end{tabular}


0.0629

154

76.990

61.6

There are 5 (five) pasi on Nusalaut island with the whole total of pasi area is 2,874.478 ha. By the total of areal width, if it is multiplied with density of fish based on biosonic recordings, it is found that red snapper potential source on Nusalaut Islands is 188 individual/ha. Then, maximum sustainable yield is 93.91 individual/year and total allowable catch (TAC) is 75.1 individual/year (Table 8).

Table 8. Name, area, density, standing stock, MSY and TAC of red snapper on Nusalaut Island

\begin{tabular}{rrrrrrr}
\hline No & Name of Pasi & Area & Density & \multicolumn{1}{c}{ SS } & MSY & \multicolumn{1}{c}{ TAC } \\
\hline 1 & Komuhatanyo & 849.4390 & 0.0180 & 15.2899 & 7.6450 & 6.1160 \\
2 & Hapuyo & 613.5210 & 0.0900 & 55.2169 & 27.6084 & 22.0868 \\
3 & Elmenanyo & 557.7000 & 0.0488 & 27.2158 & 13.6079 & 10.8863 \\
4 & Kakiwaihanal & 534.8830 & 0.0440 & 23.5349 & 11.7674 & 9.4139 \\
5 & Hanupunyo & 318.9350 & 0.1259 & 40.1539 & 20.0770 & 16.0616 \\
\hline & Total & $2,874.478$ & 0.0653 & 188 & 93.91 & 75.1 \\
\hline
\end{tabular}

Potential analysis result at maximum sustainable yield of red snapper species on Lease Islands is 400.33 individual/year with its biomass is 0.455 ton per year. This amount is different if it is compared with potential guesstimate for deep sea red snapper types in the other tropical waters'. As reported by Lakoni et al (1990), he estimates maximum sustainable yield (MSY) of six species red snapper on Shouten Island, Papua New Guinea is $191 \mathrm{~kg} / \mathrm{sea}$ mile, while according to Fry et al (2006), MSY of six species red snapper in Lihir Island, Papua New Guinea is $172 \mathrm{~kg} / \mathrm{sea}$ mile. Potential value of the deep sea red snapper (bae fish) on Lease Island is expected to be utilized to fulfill people's needs and can be expanded for other needs such as marine tourism by arranging spatial sites and organizing the amount and size of allowable caught fish.

\section{Conclusion}

There are 4 species of identified red snapper types in pasi, they are Etelis carbunculus, E. coruscans, E. radiosus and Aphareus rutilans. These fish types are distributed in the depth of sea ranging from $90-140 \mathrm{~m}$ in a varied measurement. The following are lists of calculated measurement that the density of fish is 0.0477 individual $/ \mathrm{m} 2$, biomass is $0.00005 \mathrm{ton} / \mathrm{m} 2$, standing stock is 800.67 individual, potential at MSY level is 400.33 individual/year and the total allowable catch (TAC) is 320.267 individual/year. Based on island region, Saparua Island has density of fish school is 0.0349 individual $/ \mathrm{m} 2$, sustainable potential is 400 individual/ha, potential at MSY level is 200 individual/year, and TAC is 160,086 individual/year. On Haruku Island, the density of density of fish is 0.0269 individual $/ \mathrm{m} 2$, sustainable potential is 154 individual/ha, potential at MSY level is 76,99 individual/year, and 
TAC is 61,6 individual/year. On Nusalaut Island, the density of fish value is 0.065 individual $/ \mathrm{m} 2$, sustainable potential is 118 individual/ha, potential at MSY level is 93,91 individual/year, and TAC is 75,1 individual/year.

\section{Credits}

This credit is intended to the donor institution (NUFFIC Netherlands) and PT MDF Pacific Indonesia (MDF PI in Bali) who have facilitated the study. It is also intended to the government and the Lease community for their contributions during this study.

\section{References}

Allen G Steener R Humann P, \& Deloach N. (2003). Reef Fish Identification Tropical Pacific. New World Publication, Inc. Jacksonvile, Florida USA.

Allen G. R. (1985). FAO species catalogue. Vol. 6. Snapper of the world. An annotated and illustrated catalogue of Lutjanid spesies known to date. FAO Fish. Synop.125, 6, 1-208.

Anderson WD Jr., \& GR Allen. (2001). Lutjanidae. in Carpenter KE \& VH Niem (Eds). FAO Species Identification Guide for Fishery Purposes. The Living Marine Resources of the Western Central Pacific. Volume 5. Bony fishes part 3 (Menidae to Pomacentridae). FAO, Rome. Pp. iii-iv, 2791-3379.

Andrade F. M. (2003). A Comparison of life Histories and Ekological Aspect Among Snappers (Pisces Lutjanidae). Lousiana State University and The Agricultural and Mecahnical Collage. Disertation.p.194.

Dichmont C. M., \& SJMBlaber. (2003). Assessment and management of snappers in the tropical Australasian region. Deep Sea 2003: Conference on the Governance and Management ofDeep-sea Fisheries.FAO Fisheries Proceedings 3/2.

Fry GC, D. T., Brewer, WN Venables. (2006). Vulnerability of deepwater demersal fishes to commercial fihing: Evidence from a study around a tropical volcanic seamount in Papua New Guinea., www.sciencedirect.com (02 Agustus 2006).

Haight W. R, D. R. Kobayashi, K. E. Kawamoto. (1993a). Biology and management of deepwater snappers of the Hawaiian Archipelago. Mar. Fish. Rev. 55 (2), 20-27.

Hukom et al (2007). Penelitian Sumberdaya Perikanan Kakap Laut Dalam (Sub family:Etelinae) di Selat Makassar dan Laut Sulawesi. Laporan Komulatif Riset Kompetitif. Pusat Penelitian Oseanografi LIPI. Jakarta.

Hunter C. (2001). Stock asseament of ruby snapper (Etelis carbunculus), Honours Thesis, University of Queensland.

Lokani P, H., Pitiale, A., Richards, G., \& Tiroba G. (1990). Estimation of the unexploited biomass and maximum sustainable yield for the deep reef demersal fishes in Papua New Guinea. In: Polovina, J., Shomura, R. (Eds.), United States Agency for International Development and National Marine FisheriesService Workshop on Tropical Fish Stock Assessment. Honolulu, Hawaii,5-26 July, NOAA-TM- NMFS-SSWFSC-148, pp. 29-55. 
Manooch C. S. (1987). Age and growth of snappers and groupers. In Polovina. JJ Ralston S. (Eds). Tropical Snappers and Groupers. Biologi and Fishery Management. Westview Press. Boulder. CO. pp 239-373.

Matrutty DDP (2011). Pasi Sebagai Daerah Penangkapan Ikan Bae (Etelis spp) di Kepulauan Lease Provinsi Maluku. Prosiding Seminar Nasional Pengembangan Pulau-Puau Kecil dari Aspek Perikanan Kelautan dan Pertanian. Cetakan I. Penerbit Direktorat Kemahasiswaan, Institut Pertanian Bogor. Hlm 232 -238.

Matsuyasu M. (2003). Management of the northweastern Hawaiian islands deep-slope bottomfish and seamound groundfish resources. Workshop papers. Deep Sea 2003. Conference of Governance and Management of Deep-sea Fisheries. FAO Fisheries Proceedings 3/2. Rome

Mees CC (1993). Population biology and stock assessment of Pristipomoides filamentosus on the Mahe Plateau, Seychelles. J. Fish Biol. 43, 695-708.

Moffit RB. (2003). Biological data and stock assessment methodologies for deep-slope bottomfish resources in the Hawaiian archipelago. Workshop papers.Deep Sea 2003. Conference of Governance and Management of Deep-sea Fisheries. FAO Fisheries Proceedings 3/2. Rome

Pilling, G.M. et al (2000). Validation of annual growth increments in the otoliths of thelethrinid Lethrinus mahsena and the lutjanid Aprion virescens from sitesin the tropical Indian Ocean, with notes on the nature of growth increments in Pristipomoides filamentosus. Fish. Bull. 98, 600-611.

Prisantoso BI dan Badrudin (2010). Kebijakan Pengelolaan Sumberdaya Kakap Merah (Lutjanus spp) di Laut Arafura. Jurnal Kebijakan Perikanan Indonesia Vol 1. Hlm 71-18.

Ralston S and HA Wiliams (1989). Numerical intergration of daily growth increments and efficient means of ageing tropical fishes for stock assessment. Fish Bull U.S. 87, 1-16.

Ralston S and GT Miyamoto. (1983). Analyzing the width of daily otolith increments to age the Hawaiian snappers. Pristipomoides filamentosus. Fish. Bull, 81, 523-535.

Ralston S. and KE Kawamoto. (1988). A biological assessment of Hawaiian bottom fish stocks, 1984-87. U. S. Dep. Commer., NOAA, Natl. Mar. Fish. Serv., Southwest Fish. Cent. Admin. Rep. H-88-8, Honolulu, Hawaii, 60.

Ramm DC. (1995). Dynamics of the Deepwater Snapper (Pristipomoides) Resources in Tropical Australia. Joint FFA/SPC/ Workshop on Management of South Pacific Inshore Fisheries. Noumea. Caledonia, 26 Juni - 7 Juli 1995.

Sudekum AE, JD Parrish, RI Radike, S Ralston. (1991). Live history and ecology of large jaks in undisturbed shallow, oceanic communities. Fish. Bull. U.S. 89, 493-513. 